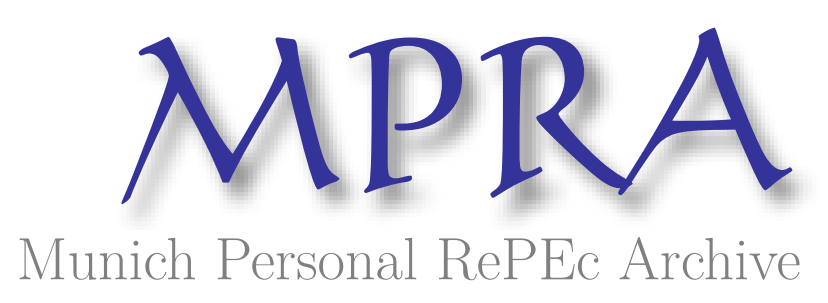

\title{
Institutional Traps and Transition
}

Polterovich, Victor

Central Economics and Mathematics Institute

1999

Online at https://mpra.ub.uni-muenchen.de/20126/

MPRA Paper No. 20126, posted 19 Jan 2010 00:17 UTC 


\title{
INSTITUTIONAL TRAPS AND TRANSITION
}

(C) 1999 г.

\author{
Victor M. Polterovich
}

Central Economics and Mathematics Institute;

New Economic School

Two myths have harmed many economies throughout the world. One is the theory of absolute advantage of central planning over the market mechanism, and the other is the belief that efficient markets develop spontaneously and quickly enough if appropriate economic legislation is established. Volumes have been written to debunk the first myth. The falsity of the second needs to be better understood.

The problem is that inside of any legislated change there exists a room for development of different institutions, or behavior norms, and it is not simple to predict which direction will be chosen by an economy. The hypothesis that efficient institutions must arise because of natural selection does not prove to be truthful. Inefficient development can be self-supporting and stable. The supporting mechanisms were systematically investigated by Arthur (1988) for technological changes. North (1990) pointed out that the same mechanisms plaid an important role in the evolution of institutions. A number of examples have been studied in different branches of economics. The most striking examples can be found in recent history of economic reforms in Russia and East European countries.

This chapter uses the ideas by Arthur and North to describe a general scheme for the formation of inefficient yet stable norm or institutions, referred herein as institutional traps. ${ }^{1}$ The scheme is substantially based on the concepts of transaction costs, transformation costs, and transitional rent discussed below. Then the theory developed is applied to explain emergence in Russia of barter, mutual arrears, tax evasion, corruption, and some other institutional traps. Implications for reform strategy are explored. The analysis shows that the formation of institutional traps is a major risk in any reform process, and avoidance of these traps is an urgent task during transition.

\footnotetext{
${ }^{1}$ The exposition follows Polterovich (1999).
} 


\section{INSTITUTIONAL TRAPS}

A norm is a rule which large groups of people obey, or can or must obey. In any area of life and at each moment in time, a multitude of alternative norms is available, and many factors influence the norm-forming process. For example, either corruption or honest service can be the norm in a bureaucratic system. Which of two stereotypes will be prevalent depends on such fundamental factors as the size of wages earned by the bureaucrats in comparison to other citizens; such organizational factors as the system of control over, and punishment for, corrupt practices; and such societal factors as the readiness of colleagues and clients to cooperate under extortionist pressure or, on the contrary, to resist corruption. For other norms of behavior one can also find these three types of norm-forming factors: fundamental, organizational, and societal ones.

\section{Transaction Costs and Institutional Transformation Costs}

Two concepts, transaction costs and institutional transformation costs, are important for analyzing evolution of norms. ${ }^{2}$ In this chapter, the term transaction costs is understood as the costs of an agent's interaction with partners within the framework of a certain behavioral norm. For example, the possibility of being caught while taking a bribe would cause a transaction cost component for an official who has chosen corruption as the norm.

I refer to the costs of transition from one norm to another as institutional transformation costs, or transformation costs for short. ${ }^{3}$ Amidst large-scale reform, transformation costs are incurred by both the state and individual firms. One can list the following major articles of transformation costs:

1. Drafting a transformation project.

2. Project lobbying.

3. Creating and sustaining interim institutions to support the project.

4. Implementation of the project.

5. Adapting the system to the new institution.

\footnotetext{
${ }^{2}$ The first of these notions is widely known. According to Eggertsson (1990), transaction costs include: (1) search for information on a product/service and search for a prospective transaction partner; (2) bargaining, and the preparation and signing of an agreement; (3) control over and enforcement of compliance with transaction agreement; (4) settlements under, and formalization of the agreement in the process of its implementation; (5) the agreement's protection from third parties (e.g., from the tax-collecting authorities in the event of an illegal agreement).

${ }^{3}$ Some authors use the term transformation costs in a different sense, meaning the costs of resource utilization. In this paper, it always refers to the costs of institutional transformation.
} 
Any transformation, especially a large-scale one, leads to some kind of system disruptions (see discussion below) that aggravate the adaptation costs. Any draft project of reforms must include an assessment of the relevant costs. ${ }^{4}$ Despite the obviousness of this point, when Russian reforms were proposed, the issue of costs was totally neglected.

\section{Norm Stability and Norm-Fixing Mechanisms}

For a behavioral norm to be stable, individuals should feel that it would be unprofitable or disadvantageous for them to deviate from it. In other words, stability should be ensured through the use of some kind of stabilizing mechanism a mechanism with negative feedback. Such mechanism can rely directly on the structure of individual preferences. For example, the "wash your hands before each meal" norm is supported by personal hygienic considerations. Another mechanism has to do with punishment for a norm's violation that may be envisaged under the law or supported by the local tradition. A third and far more interesting type of stabilizing mechanism is based on the so-called coordination effect secured by a type of externality. According to the coordination effect, the more consistently a norm is observed in society, the greater the costs incurred by each individual deviating from it. For example, the coordination effect takes place if a personal probability to be punished for a rule-breaking activity depends negatively on the number of people involved in the activity.

With time, the prevalent norm becomes fixed as a result of the agents learning to be more efficient in terms of that norm's observance and thus perfecting their implementation skills. If the payment of taxes is considered the norm within a society, the declaration-filling and taxpaying habits of its members will be improving. If, on the contrary, tax evasion is the norm, then the relevant techniques will be developing first and foremost. This is what is called the learning effect (although, perhaps, perfection effect would be a more relevant term ${ }^{5}$ ), which slashes transaction costs as a result of public compliance with the norm.

No less important is another phenomenon, herein referred to as the linkage effect. With time, an established norm finds itself linked with a multitude of other

\footnotetext{
${ }^{4}$ Rodrik (1996) discusses the reform difficulty indicator as the ratio of income redistributed in the reform process, to gains from increased system efficiency. In certain cases this indicator, referred to as the political cost-benefit ratio, can be effectively assessed.

${ }^{5}$ Arthur considers the learning effect for technical changes. He argues that as certain products hit the market, their quality improves or their production becomes less costly (see Arthur (1988)), which essentially implies some perfection. Learning models are dealt with in Arthur (1994), Chapter 8.
} 
rules, and becomes part of a system of other norms. Therefore, non-observance of this norm would be sure to trigger a chain of other transformations and, consequently, lead to high (linked) transformation costs. By increasing transformation costs, the linkage effect, too, contributes to a norm's fixation.

Finally, there is yet another norm-fixing mechanism, cultural inertia, which denotes agents' reluctance to review those behavioral stereotypes that have already proven viable. Inertia effects may be supported by a formal or informal system of punishments and awards for the past behavior. For example, a person with good reputation tries to save it following the respectable norms of conduct.

When a norm undergoes transformation, the relevant transformation costs are distributed among the agents unevenly. This, together with cultural inertia and uncertainty about the amount of the transformation costs, leads to the emergence of conservative pressure groups resisting any change to the norms that are effective at the moment.

In cases where two or several different norms are not equivalent, one norm may be Pareto dominated. In many situations, however, Pareto's comparisons are not sufficient to weigh norms against one another; they should be assessed based on other criteria, such as social utility or efficiency. We will henceforth refer to an inefficient stable norm (inefficient institution) as an institutional trap. ${ }^{6}$ As with any other norm, an institutional trap's stability means that a system absorbing a small external impact will remain in the institutional trap, having perhaps slightly changed its parameters, and will return to the former state of equilibrium once the source of destabilizing pressure is removed.

An individual or a small group of people loses if it deviates from an institutional trap behavioral stereotype. However, the simultaneous adoption by all agents of an alternative norm would help raise the level of public well-being.

The emergence of institutional traps is a major source of risk associated with any reform process. The universal mechanisms described above, the coordination, learning and linkage effects, as well as cultural inertia, are responsible for institutional trap forming, too.

The structure of stable norms substantially depends on transformation costs. Although it would appear that such costs should only enhance a system's stability

${ }^{6}$ Arthur and North use the term "lock-in". 
by leaving the no rms themselves intact, a closer look at the problem shows that transformation costs can lead to the emergence of new stable equilibria - namely, mixed norms of behavior. In a state of mixed equilibrium, the advantages of one norm over another are reduced to nil by the transformation costs, and agents can partially follow two or several patterns of conduct.

Transformation costs are increased through the linkage effect and can support an originally inefficient norm even when the coordination effect stops working. Once fallen into an institutional trap, the system chooses a non-efficient path of development, and with time, returning to efficient development may not make sense any longer. Moreover, a system with a prevalent efficient norm, if strongly disturbed (with the set of equilibria, however, remaining structurally unchanged), may fall into an institutional trap in which it will remain even after the disturbing factor is removed. This is the so-called "hysteresis effect" ${ }^{7}$, which is typical to all norm-forming processes, including those involving institutional traps.

\section{INSTITUTIONAL TRAPS IN RUSSIA}

The large-scale reforms pursued in the Eastern Europe in the 1990s have clearly shown the need for a consistent theory of institutional economic change, and proved that the state of this theory was anything but satisfactory. Russia has had a particularly bitter lesson to learn. The consequences of the transformations were unexpected by experts, whatever guideline direction of the reform process you could look at. Once freed, the prices began to rise more steeply and continued to soar for a longer period of time than most experts thought they would. The rush to bring the prices under control produced a system of mutual arrears and provoked a shift towards barter trading, which actually meant that a non-monetary economy took shape on a new basis. Attempts to change the tax-collecting system gave a boost to shadow economy development. The slackening of state control over cash flows - a measure expected to create a competitive economic environment - fueled corruption. The "shock privatization" campaign, instead of producing efficient private property holders, gave birth to such inefficient organizations

\footnotetext{
${ }^{7}$ The term has been borrowed from physics. In certain cases the state of a system is dependent not only on the value of its exogenous parameter but also on whether that value results from the parameter's decrease or increase. That is what is called hysteresis. If we have changed the state of a system by increasing the parameter (in our example, the transaction costs of monetary exchange), then, considering the hysteretic lag in the system's returning to its original state, we need to decrease the parameter to a value below the original one. Hysteresis is a form of a system's dependence on its former path of development (path dependence).
} 
as open-end stock companies owned by their employees. And all those changes were accompanied by an unforeseen and uncommonly sharp production decline.

Many of these unexpected phenomena are institutional traps. They are responsible for the misfortune of the Russian economic reforms. Using the concepts discussed above one can explain their emergence to extract lessons for the future.

\section{Barter}

Barter is often an attending circumstance to fast inflation. In modern economies, barter is associated with higher transaction costs than monetary transactions. Therefore, barter exchanges are rather scarce today. When inflation rate increases, paper money loses its value. Economic agents try to diminish their losses and seek to accelerate the rates of money circulation, which means an increase of their transaction costs. The transaction costs of monetary exchanges may grow very rapidly, if the finance system fails to cope with the rocketing number of transactions.

In economies with advanced banking systems the share of barter is rather modest even when inflation is high. But after price liberalization of 1992, Russia proved to be ripe for barter (see Polterovich (1993)). With the banking system still unformed, money transfers within Moscow could take up to two weeks, and beyond the capital city's borders, over a month. It sometimes made more sense to carry bags of cash from city to city by plane than to transfer money from one bank account to another. Many firms soon found that barter transaction costs were lower than those for monetary exchange. Moreover, the transformation costs of a shift to barter looked acceptable due to the old-time direct links between supplier and consumer that had been the pride of the centrally-planned economy. The search for prospective counterparts and the process of trade negotiations were facilitated by the spread of sophisticated means of communication. The larger the number of firms choosing barter, the lower the barter transaction costs for a fixed barter volume since it was easier to find partners and put together barter chains (a coordination effect). In those conditions, as the share of barter exchanges increased, even more companies became involved.

Thus the environment conducive to barter had been created by changes in such fundamental factors as the rates of inflation and the risk of arrears, which radically changed the ratio of monetary exchange transaction costs to barter exchange transaction costs. The coordination effect triggered rapid formation of the 
relevant norm. Later the transaction costs of barter exchanges continued to decrease due to the learning effect: companies learned to design elaborate chains of barter exchanges. The newly established norm gave birth to a new institute of barter exchange intermediaries and proved to be an efficient instrument of tax evasion (linkage effect).

By 1997, inflation in Russia had gone down dramatically, and monetary exchange technology had notably improved. Barter practices, however, were not dropped altogether. ${ }^{8}$ Barter-driven behavior is supported by the coordination effect; it has been fixed through learning, linkage, and cultural inertia. Any agent deciding to break out of the barter system would have to expose itself to inevitable transformation costs: sever the long-established connections, look for new partners, and be ready to come face to face with the tax-collecting authorities. That is why imposition of legal sanctions for barter practices might lead to a temporary additional decline in production, and a high level of social transformation costs. ${ }^{9}$ The barter intermediaries, who would lose their chief sources of income if barter practices were eliminated, are definitely a potential group of pressure for perpetuation of the relevant norm. ${ }^{10}$

Price liberalization and the subsequent inflationary shock exerted cumulative pressure on the system, causing institutional changes. However, when inflation and monetary exchange transaction costs diminished, the system did not return to its initial state. What we can see here is the hysteresis effect mentioned earlier.

Depending on the size of transaction costs, a company may choose to barter one product and sell another for money. One should consider also the mixed norms of behavior that may prompt a company to do so. At a mixed equilibrium, the difference between marginal costs of the barter and monetary exchange may fail to offset the marginal costs of transformation, thus making both increased and decreased monetary exchanges unprofitable.

\footnotetext{
${ }^{8}$ For a detailed description of the barter exchange mechanism see Kleiner, Makarov (1996). By various estimates, between 50 and 80 percent of all exchanges among the producer companies were barter-based in 1997 . It should be noted that Russian Federation Pension Fund officials actively helped enterprises to organize barter chains in order to increase cash flows into the Fund's budget. The Fund head Barchuk, V. recalls that the would-be Premier Kirienko, S., who still worked in Nizhny Novgorod at the time, succeeded in seeing through one of the most elaborate schemes of barter exchanges (see Rubchenko (1998)).

${ }^{9}$ Hence V. Barchuk's observation that you cannot do away with barter overnight (Rubchenko (1998)).

${ }^{10}$ Of course, it is a very stylized description of the events. Two norms, barter and arrears, both are caused by expensive real money and are substitutes in a sense: agent can choose between two possibilities to avoid payments.

Sometimes arrears are an implicit form of barter (see below). One can note also that high price of real money was supported by a very high rate of return of government bonds in 1997-1998.
} 
The above analysis suggests price liberalization requires an economy with sufficiently advanced monetary institutions, thus securing low-level transaction costs even when inflation is high. Otherwise the system is susceptible to a barter trap.

\section{Arrears}

If an enterprise fails to pay to its suppliers, it undermines their solvency and risks triggering an avalanche of mutual arrears. In developed economies, avalanches of this kind can be averted due to the efficient credit institutions and enforcement mechanisms that are in place, such as bankruptcy proceedings or company restructuring. When prices were freed in Russia in 1992, inflationary shock emptied company bank accounts. As noted earlier, transaction payments lagged severely, the credit system worked by fits and starts (although with a negative real interest), and there were no bankruptcy law or restructuring mechanisms at all. Coming under the effects of those fundamental and organizational factors, most enterprises found that instead of waiting until the buyers of their products paid in full, they, too, could offer only partial payment. ${ }^{11}$ Underpaid suppliers of materials would be unlikely under the circumstances to terminate further shipments for fear of losing their clients altogether; besides, breaking the tacit rule "If you can't pay, don't claim payments from others" might backfire with similar sanctions from the angry community of other non-payers. The coordination effect thereby formed fixed the mechanism of mutual arrears as a stable norm which was further strengthened through linkage with barter and tax evasion. ${ }^{12}$ As a result, application of the bankruptcy law was fully blocked by mutual arrears that had become a universal practice. ${ }^{13}$

\footnotetext{
${ }^{11}$ The mechanism of arrears was studied in a number of papers (see Polterovich (1993), Calvo and Coricelli (1994), Gomulka (1994)).

${ }^{12}$ A company is not motivated to claim payments from its consumers if all funds credited to its account are automatically transferred to the state budget, as was the case with the blacklisted non-payers in Russia in 1995-97.

${ }^{13}$ It should be noted that many enterprises did their best to balance out their payables and receivables. If such a balance were kept up by each company, the mechanism of arrears could have developed into a form of barter exchanges which, however, would have been marked by a high degree of uncertainty and, consequently, by still higher transaction costs. Let us also point out that the government's own systematic non-fulfillment of obligations notably strengthened the mechanism of mutual arrears.
} 


\section{Tax Evasion}

For an economic agent, the strategic choice between the payment and nonpayment of taxes is determined by a number of fundamental and organizational factors. The first group includes taxation policy and government expenditure policy.

To avoid non-payment, citizens need to be assured that the money they pay will help improve their well-being (in a broad sense) and be spent with due efficiency. Lack of such assurances puts an edge on the free-rider problem. With the state performing inefficiently, tax evasion may prove to be the most clever behavioral option not only for each individual free-rider but also for society as a whole. Non-payment of taxes becomes morally justified. Public confidence decreases especially rapidly if the government imposes higher tax rates and slashes social expenditures at the same time, as the Russian government has done in 1992-98, because people fail to see any positive effect from the growing tax burden.

For anyone making strategic choice in the tax sphere, it is perhaps more important to consider the organizational factor, i.e., the system of enforcement causing a person to expect tax evasion to be dangerous. When sweeping reforms were launched in Russia, its tax-collecting service was still rudimentary, its enforcement machinery was very weak, and its tax police would not be formed until 1997.

Where tax rates are too high and the enforcement mechanisms are inefficient, tax evasion looks attractive to many economic agents. The individual's chance of being caught is too small. The more widespread the non-paying practice, the less tangible the damage one can expect to incur as a result of refusing to pay. This coordination effect gives an additional incentive for still bolder tax evasion.

Mass tax evasion leads to the emergence of an appropriate service system involving numerous mediators, creators of one-day firms, and designers of new tax evasion schemes (Dolgopyatova (1998)). As usual, the learning effect is accompanied by the linkage effect: special organizational forms of production appear; false accounting and reporting becomes widespread; tax evasion conjoins with barter, arrears, and corruption. A firm wishing to quit the shadow sector would be exposed to high transformation costs; besides, having paid once, it 
would remain under the tax-collectors' scrutiny for the rest of his days. Therefore, small-scale financial injections into the tax-collecting system can only lead to a further swelling of costs in the tax evasion system, thus adding to the overall exhaustion of the economy. Modest tax rate reductions cannot help either: the nonpayers will continue to evade taxation, and the law-abiding taxpayers will start to pay less. This is a bright illustration of what the hysteresis effect is.

\section{Corruption}

Every potential bribe-taker makes decisions comparing his/her gains from bribes and from honest behavior. In Russia, income inequality jumped sharply during transition because uneven transitional rent expropriation (see next section). The state was not able to adjust properly the salaries of bureaucrats which turned out to be insignificant in comparison to bribes from the new rich. It was a base for an increase in corruption activity. Inefficient government policy, inadequate legislation, unclear norms of new market behavior, and weak mechanisms of state and public control contributed to a rise in corruption.

The larger the scale of corruption, the smaller the chances for a bribe-taker to be caught or condemned. This external dependence underlies the coordination effect adding stability to a corrupt system which, with time, tends to perfect itself and build an internal hierarchy linked with other shadow economy mechanisms. ${ }^{14}$

\section{Foreign Trade-Related Economic Stagnation}

Extreme trends in foreign trade policy can lead a country into an institutional trap. Over the past 20 years, much criticism has been voiced in the scientific community with regard to protectionist, import-substitution strategies of economic development. Barring domestic producers from competition with peers in the world market distorts the structure of protected industries and gives them no incentive to work better. Unlike the case studies described above, there is no coordination effect here. The cumulative impact of macroeconomic policy is based on the learning and linkage effects: protectionist attitude to one industry affects via prices - the production structure and consumer stereotypes throughout the economy. Attempts to change protectionist policies can be blocked by resistance from lobbyists, leading to the institutional trap's fixation.

\footnotetext{
${ }^{14}$ In fact corruption traps were studied in many papers. See for examples Lui (1986), Tirole (1993), Polterovich (1998), and references in Bardhan (1997).
} 
But a premature, ill-prepared attempt to liberalize foreign trade also leads to an institutional trap. This problem arises in technologically backward countries, like Russia, rich in raw materials. These resources are processed into consumer goods of such poor quality that they cannot be sold on the world market. For such countries, the best short-term strategy would be to invigorate exports of raw materials, curtail domestic production, and spend the bulk of export revenues on internal consumption. That, however, would inevitably lead to the closure of manufacturing enterprises and to mass unemployment. Unemployment involving a sizable part of the population would be bound to have a destructive cumulative effect: declining labor skills, a wider gap in incomes, higher social tensions, rising crime, and social apathy. Such policy would be sure to result in the national economy's collapse when the raw material sources have been exhausted, or even sooner, in the event of a change for the worse on the world market for raw materials. Hence the best long-term strategy is to aid domestic production with subsidies that are gradually removed as modern technology is purchased with the help of export revenues.

A country with an unstable political system would be more likely to choose the short-term option. The longer the period during which the food-for-raw- materials policy is pursued, the higher the transformation costs, and the greater the difficulty such country faces shifting towards a cleverer behavioral norm. The system thus would finds itself in an institutional trap.

The cumulative effects of mass unemployment due to interaction with a more advanced economy has been especially pronounced as far as the ethnic groups inhabiting Russia's Northern regions are concerned. The rapid degradation over the few decades has occurred despite considerable financial assistance intended to integrate these nationalities into European civilization. This should serve as a serious warning to the proponents of shock therapy. The recently discovered negative correlation between rich natural resources and economic growth in developing countries (see references in Rodrik (1996)) obviously demonstrates that it is very difficult to resist the temptation of choosing the short-term strategy option.

\section{Institutional Conflict}

History knows many futile attempts to transfer institutions from one cultural environment to another. It is not accidental that economic mechanisms in once 
backward, but now rapidly progressing countries, such as Japan, South Korea or China, are strikingly different from their American or European prototypes. It is all the more surprising that in the process of Russian reforms no one has actually raised at the government level the issue of how much the US institutions (which were chosen for replication in this country) are compatible with Russia's cultural tradition. Meanwhile, cultural inertia could not fail to exert its influence on the forcibly imposed institutional innovations.

Conflict between established and newly introduced norms sometimes gives birth to non-viable institutions (such as Russia's Bankruptcy Law passed at the peak of the mutual arrears crisis), although occasionally it generates some stable but inefficient mutant structures which essentially constitute a kind of institutional trap.

A bright example of such mutant structure is the open joint stock company controlled by its workers, a new type of enterprise that emerged during Russia's privatization campaign. ${ }^{15}$ Seeking to avoid the formation of collective enterprises (that are difficult to restructure) and to breed a Western-style corporate system on Russian soil, the government produced a hybrid utterly unprepared for efficient development. If the majority of such company's shares are distributed among its management and personnel, the managers cannot afford mass layoffs because, if the fired workers sold their shares to external investors, the old management would be likely to go. For similar reasons, the staff should be very careful about dismissing their managers because, if the latter sold their stock, the company might change hands, and unemployment might loom large over the workers. Many Russian firms have redundant staffs and suffer from manager incompetence; their paradoxical organizational structure, however, prevents them from cutting labor costs or inviting new managers.

\section{Reform Process AND THe State}

Since reforms are implemented by government, the state inevitably plays a decisive role during a period of major reforms. This holds true even when reforms are aimed at decreasing the role of the state. When launching a reform campaign, the government influences the future of citizens and manipulates assets far more than under normal circumstances.

\footnotetext{
${ }^{15}$ One can meet similar mutants in other countries also but this form does not dominate usually.
} 
The role of government is often measured by the share of expenditure in GDP. This indicator reflects the state's ability to redistribute resources within systems with established institutions, but is absolutely irrelevant, for instance, at a time of mass privatization when the value of the flow of redistributed assets increases many times over. It is this circumstance that makes market reforms possible: a government pursuing the reforms weakens the positions of its future successors, rather than its own positions.

Large -scale economic reform is not an act of creation, it is a process that requires good preparedness of the economy reforming, right choice of rate and sequence of the reform, effective provisional institutions, and consistent discretionary economic policy. Avoidance of the institutional traps is one of the important tasks of the reformative state.

\section{Transitional Rent and Reform Failures}

Any limitation imposed on the free flow of resources or the level of prices is equal to a privilege generating additional (as assessed against competitive equilibrium) rental income. A major source of such income in the Soviet-style economies was the margin between wholesale and retail, as well as domestic and world, prices. The bulk of the rent went into the state budget to be redistributed, and the rest was stolen by high-rank officials and shadow dealers. The freeing of prices was expected to eliminate the rental income together with the opportunities for abuses associated with it. Comparison of the prevailed regime with competitive equilibrium was fully in favor of the latter; hence the conclusion that lifting the limitations and ending government interference would be sufficient to quickly raise efficiency. The error was rooted in disregard for the transitional period difficulties. It had less dramatic consequences for smaller countries with more advanced economic mechanisms, more efficient banking systems, and prices approaching world prices. Russia's losses, however, have been tremendous.

At a time of economic liberalization, some economic agents are able to derive additional income - transitional rent - exclusively from their prominent position. Price liberalization gives the advantage to suppliers of goods in high demand. Foreign trade liberalization allows importers and exporters to profit from differences in domestic and world prices. The emergence of new stock exchanges and securities markets creates ample arbitrage opportunities for banks. 
Until 1992, because of the foreign trade monopoly, all rental income derived from the low prices of raw materials in Russia was collected by the state. Some of it was lost because government officials were inefficient and corrupt, and the rest went into the state budget. The obvious deficiencies of this mechanism served as an argument for a shock liberalization of prices and foreign trade. The underlying idea was the following: once the domestic prices balanced out with the world prices, the rent income would be eliminated, exporters would be given the necessary market incentives, government would no longer need to regulate economic performance, and there would be no losses at all.

This logic is faulty, apart from the impact of liberalized foreign trade on domestic production. In a country like Russia, with its vast territory and its weak inter-regional ties, it takes years to attain a post-liberalization equilibrium. During the transitional period private firms continue to earn the rental income which the state has rejected. Although this income tends to diminish gradually, it is so high at the initial stage that those finding themselves in the right place at the right time can get fantastically rich overnight. Since income reinvestment mechanisms are yet to be created, the income is spent on consumption by a small group of individuals, while the majority of the population is falling into poverty. ${ }^{16}$

Price liberalization does not result only in redistribution of rental income abandoned by the state. During the transition period part of that rent gets dissipated because resources are spent on the search for an equilibrium. Specifically, losses occur because the economic agents' activities lack coordination Firms try to use new opportunities and break long chains of traditional connections that lead to disorganization (Blanchard and Cremer 1996). In the course of the search process, some production capacities stay idle because of a lack of raw material supplies or demand for the final products, and some of the products already manufactured cannot be sold. Losses of this kind are included in transformation costs. Apparently, they are a major cause for what is referred to as "transformational recession".

The appropriation of transitional rent causes jumps of income inequality and the crime rate which are observed in many economies in transition. As a result the system may fall into a corruption trap. Lack of coordination and the dissipation of rental income entail insolvency of many enterprises and contribute to the forming

${ }^{16}$ The notion of transitional rent is introduced in Polterovich (1998), similar ideas can be found in Gelb, Hillman, Urspring (1996). 
of the mechanisms of arrears and tax evasion. Reforms should be good prepared to diminish the transitional rent and to have most part of it collected by the state.

\section{Rate, Preparedness, and Sequence of Reforms}

One of the important parameters of the reform process is the rate of reforms. ${ }^{17}$ Proponents of shock therapy argue that reforms are similar to a surgery that has to be done as quickly as possible to minimize suffering. They also point out that reforms will be irreversible if their opponents do not have enough time to consolidate. Neither argument permits any doubt as to the expediency of the reforms. A more subtle and perhaps more valid point made by the supporters of shock therapy is that reforms can only be launched if the threshold values of certain parameters have been exceeded. For example, it would be silly to privatize just one enterprise; privatization can only be efficient when there is a sufficient number of privatized firms with a market infrastructure of their own.

An alternative, gradualist viewpoint is based on three key arguments. First, conducting reforms and creating new institutions requires the availability of funds to finance the relevant transformation costs. If we look at the proposed plan of reforms in a package with other potential investment options, the overall target being to optimize consumption for a certain period, we will be able to design a wellbalanced strategy that, typically, should provide for the gradual nature of any transformations.

Second, one can never be sure that the original plan of reforms will not have to be amended. No one can guarantee that the proposed changes will not lead the country into institutional difficulties. When reforms are too rapid, it is impossible to make interim assessments or correct mistakes.

Third, reforms should be thoroughly prepared ${ }^{18}$ and duly sequenced. As discussed above, shock liberalization of prices will inevitably lead to a barter and arrears traps if there is no efficient banking system to avoid inordinate transaction costs during the period of soaring prices. Similarly, foreign trade liberalization

\footnotetext{
${ }^{17}$ The rates of reforms have been discussed in the scientific community largely in conjunction with privatization. See Blanchard (1997), Polterovich (1996) for a review of opinions and references.

${ }^{18}$ Reform preparedness (measured by the initial liberalization index) has been shown to be of primary importance to the successes of reform programs in the East European economies (de Melo, Denizer, Gelb, Tenev (1997), Volyanski (1997). A similar conclusion was drawn from the experience of South-East Asian countries. Variations of their rates of growth between 1960 and 1994 can be largely explained by institution quality indexes (Rodric (1996)). The absence among the independent variables of macroeconomic regulation characteristics leads one to believe that macroeconomic policy impacts the long-term growth inasmuch as it impacts the formation of economic institutions.
} 
should not occur before the domestic market has been sufficiently liberalized and a system of (temporary) export tariffs has been introduced for purposes of collecting the transitional rent. In an economy with non-flexible and unbalanced prices, the positive effects of market expansion and import growth can be reduced to naught because of the outflow of resources, high rates of unemployment, or considerable differentiation of income caused by the lifting of controls over exports and imports.

Gradual approach does not necessarily delay positive transformations of the economic mechanism. On the contrary, good preparation and sequencing accelerate the success of reforms.

Experience of large-scale transformations reveals an important specific aspect of macroeconomic policy in economies in transition. If market mechanism is well developed, macroeconomic policy influences mostly on macroeconomic indicators as exchange rate, inflation, or GDP. For a country with unstable institutional structure macroeconomic impact is capable of altering that structure. In Russia, the a standard receipt for fighting inflation-tough monetary policy- promoted formation of institutional traps. The government had abandoned seignorage without having first established a reliable tax-collecting system. When the tax collection level was low, stabilization was attained through external loans, mutual arrears, and barter, which contributed to the confidence crisis in August 1998.

\section{Industrial Policy}

Industrial policy is much more important for reforming economies than for countries with good formed market institutions. The "economic miracles" of South Korea and Taiwan began not with privatization but with the creation of state-owned enterprises in promising industries. These countries liberalized foreign trade on a step-by-step basis over a 30 year period and have continued to maintain significant control over foreign investments almost to the present day. Rodrik (1996, 1995) points out that Mexico, Bolivia and Argentina, which have moved much faster in privatization and foreign trade/finance liberalization, have been far less successful than the South-East Asian economies that made ample use of such instruments as industrial policy, credit benefits, and protectionism. ${ }^{19}$

\footnotetext{
${ }^{19}$ Neoliberalism is criticized in Joseph Stiglitz's work on the Post-Washington Consensus (Stiglitz (1997)), which stresses that the government must complement the market. Stiglitz especially emphasizes government's role in human capital development and in borrowing and creating new technology. Both factors have played a decisive role in economic growth in Asia.
} 
Where reforms are pursued in a system with an unstable institutional structure and under the strong fluctuations of macroeconomic variables, the position of enterprises may be more dependent on chance circumstances than on quality management. In such a context, industrial policy acquires added importance. It should be aimed at protecting from bankruptcy selected companies and even entire industries of national significance that may be in dire straits at the moment. It is no less important for the state to initiate and support economic growth, encourage competition and regulate exports and imports by setting appropriate custom tariffs and quotas.

Indicative planning has been a useful instrument of government policy in a number of countries, especially in Japan and France during its transitional period after the Second World War (see, e.g., Cazes 1990, Sato 1990). The planning provides for a possibility to integrate different sides of the government's interference in the economic sphere and to coordinate decisions of economic agents through a system of incentives and through a dialog involving representatives of various social, economic and political groups. I think it can be useful for modern transitional economies as well.

Reforms became necessary in Russia and Eastern Europe because the system of total government control over the economy had proven its inefficiency. However, no single agent other than the government is capable of making efficient long-term decisions in situations of fundamental institutional change. If the government can not do it, the reforms are doomed to failure. Neither managers nor private entrepreneurs have the necessary planning horizon. Feeling uncertain about their future, economic agents set short-term targets, while the invisible hand of the budding market is still unable to transform egoistic strategies into socially relevant behavior. Indicative planning is expected to mitigate this inevitable deficiency of the transitional regime.

The problem of long-run decision making is facilitated by emergence of large corporations and financial-industrial groups. The process of integration has been evidenced in virtually all economies in transition, including post- war Japan, South Korea, and France. This process has already begun in Russia (Dementiev 1998). The large corporations have the necessary planning horizon to support strategic planning. The growth of corporations takes the edge off the problem of barter and arrears, facilitates the collection of taxes, and resists society's criminalization, although all that is achieved through the strengthening of monopoly power. A reasonable mix of anti-monopoly measures and support for large pro- 
ducers is essential to ensure the success of any long-term industrial policy and to overcome institutional traps.

\section{CONCLUSION}

Each institutional transformation should be preceded by efforts to forecast and forestall possible institutional traps. Such efforts should became part and parcel of preparations for any kind of reform.

Transformation costs should be taken into account. Right choice of the rate and sequence of the reforms, and wise industrial policy are prerequisites of institutional trap avoidance. An important task at the initial stage of reforms is to have most part of transitional rent collected by the state, which should diminish production losses, prevent unfair income differentiation, and hold the corruption and rent seeking activity in check.

But if a trap is formed the task of breaking out of it turns out to be very difficult. Related theory has to be developed yet. Standard temptation is imposition of much harsher sanctions for deviation from socially efficient norms. Such strategy may imply considerable expenditures and is capable to generate even worse institutional traps. The history of Russia's war against arrears and tax evasion shows how difficult it is for a country to solve the problem in that manner.

There are reasons to believe that an economy may gradually create mechanisms conducive to its exit from institutional traps; the government has to support these mechanisms. If the market infrastructure is inefficient, and, consequently, the costs of market transactions are high, then large companies would be likely to emerge. This facilitates the exit. Another important line of spontaneous development is emergency of the institute of reputation. It creates incentives for efficient personal behavior (Tirole 1993, Bicchierry and Rovelli 1996).

However it is quite possible that new reform has to be conducted to get out of institutional traps. The measures should be directed to weaken coordination, linkage, and inertia effects supporting the traps, to increase their transaction costs, and to decrease transformation costs and transaction costs of efficient norms. 


\section{REFERENCES}

Arthur, W.B. (1988). "Self-Reinforcing Mechanisms in Economics." In Anderson, P.W. K. Arrow and D. Pines, eds., The Economy as an Evolving Complex System. Santa Fe: Addison-Wesley Publishing Company, 9-28.

Arthur, W.B. (1994). Increasing Returns and Path Dependence in the Economy. Ann Arbor: The University of Michigan Press.

Bardhan, P. (1997). "Corruption and Development: A Review of Issues." Journal of Economic Literature 34, 1320-1346.

Bicchierri, C. and Rovelli, C. (1996). "Evolution and Revolution. The Dynamics of Corruption." Rationality and Society 7(2).

Blanchard, O. and Kremer, M. (1996). "Disorganization." Preprint. Cambridge: MIT and NBER.

Blanchard, O. (1997). The Economics of Post-Communist Transition. Oxford: Clarendon Press.

Calvo, G.A. and Coricelli, F. (1994). "Inter-enterprise Arrears in Economies in Transition." In: Holzmann R., J.Gacs, G.Winckler, eds.:"Output Decline in Eastern Europe. Unavoidable, External Influence or Homemade?" Laxenburg, IIASA, 193 - 212.

Gomulka, S. (1994). "The financial situation of enterprises and its impact on monetary and fiscal policies, Poland 1992-93." Economics of Transition 2 (2), 189-208.

Cazes, B. (1990). "Indicative Planning in France." Journal of Comparative Economics 14(4), 607-620.

Dementiev, V. (1998). "Integratsiya predpriyatii i ekonomicheskoye razvitiye." Preprint, WP/98/038. Moscow: CEMI RAN. (Russian).

Dolgopyatova, T., ed. Neformal'nyi sector $v$ rossiiskoj ekonomike. Moscow: ISARP. (Russian).

Eggertsson, T. (1990). Economic Behavior and Institutions. New York: Cambridge University Press. 
Gelb, A., Hillman, A. and Ursprung, H. (1996). "Rents and the Transition." Background paper, World Bank Development Report.

Kleiner, G.B. and Makarov, V.L. (1996). Barter v Rossiyskoy ekonomike. Moscow: CEMI RAN.

Lui, F.T. (1986). "A Dynamic Model of Corruption Deterrence." Journal of Public Economics 31(2), 215-236.

Melo, Martha de, Denizer, C., Gelb, A., and Tenev, S. (1997). Circumstance and Choice: the Role of Initial Conditions and Policies in Transition Economies. Preprint. The World Bank International Finance Corporation.

North, D. (1990). Institutions, Institutional Change and Economic Performance. New York: Cambridge University Press.

Polterovich, V.M. (1993). "Ekonomicheskaya reforma v Rossii v 1992: Bitva pravitel'stva s trudovymi kollektivami." Ekonomika i Matematicheskiye Metody 29(4), 265-287 (Russian).

Polterovich, V.M. (1996). "Towards the Theory of Privatization." Central Economic-Mathematical Institute, Russian Academy of Sciences. Working Paper \# WP/96/001.

Polterovich, V.M. (1998). "Faktory korruptsii." Ekonomika i Matematicheskiye Metody 34(3) (Russian).

Polterovich, V.M. (1999). Institutsional'nye lovushki I ekonomicheskie reformy. Economika i Matematicheskie Metody 35(2). (Russian).

Rodrik, D. (1995). "Getting Intervention Right: How South Korea and Taiwan Grew Rich." Economic Policy 20, 55-57.

Rodrik, D. (1996). "Understanding Economic Policy Reform." Journal of Economic Literature 34, 9-41.

Rodrik, D. (1996a). "Institutions and Economic Performance in East and Southeast Asia." In Round Table Conference, The Institutional Foundation of Economic Development in East Asia. Tokyo, 16-19 December, 391-429.

Rubchenko, M. (1998). "Bor'ba za spokoynaya starost'." Interview with Russian Pension Fund chairman V. Barchuk. Ekspert 11(17), 134. (Russian). 
Sato, K. (1990). "Indicative Planning in Japan." Journal of Comparative Economics 14(4), 625-647.

Stiglitz, Joseph E. (1997). "More Instruments and Broader Goals: Moving Toward the Post-Washington Consensus." Wider Annual Lectures 2. The United Nations University, May.

Tirole, J.A. (1993). Theory of Collective Reputations with Applications to the Persistence of Corruption and to Firm Quality. Paris: Institut d'Economie Industrielle, Toulouse, MIT and Ceras.

Volyansky, D. (1997). Inflyatsiya, retsessiya i podgotovlenost' reform $v$ stranakh $s$ perekhodnoy ekonomikoy. M.S. Thesis. Moscow State University. (Russian). 